\title{
Biochar increases plant-available water in a sandy loam soil under an aerobic rice crop system
}

\author{
M. T. de Melo Carvalho ${ }^{1,2,3}$, A. de Holanda Nunes Maia ${ }^{4}$, B. E. Madari ${ }^{1}$, L. Bastiaans ${ }^{2}$, P. A. J. van Oort ${ }^{2,5}$, \\ A. B. Heinemann ${ }^{1}$, M. A. Soler da Silva ${ }^{1}$, F. A. Petter ${ }^{6}$, B. H. Marimon Jr. ${ }^{7}$, and H. Meinke M,3 $^{2,3}$ \\ ${ }^{1}$ Embrapa Rice and Beans, Santo Antônio de Goiás, Goiás, Brazil \\ ${ }^{2}$ Wageningen University, Centre for Crop Systems Analysis, Wageningen, the Netherlands \\ ${ }^{3}$ Tasmanian Institute of Agriculture, University of Tasmania, Hobart, Australia \\ ${ }^{4}$ Embrapa Environment, Jaguariúna, SP, Brazil \\ ${ }^{5}$ Africa Rice Centre, Cotonou, Benin \\ ${ }^{6}$ Federal University of Mato Grosso, Sinop, Mato Grosso, Brazil \\ ${ }^{7}$ State University of Mato Grosso, Nova Xavantina, Mato Grosso, Brazil
}

Correspondence to: M. T. de Melo Carvalho (marcia.demelocarvalho@wur.nl)

Received: 28 February 2014 - Published in Solid Earth Discuss.: 18 March 2014

Revised: 25 July 2014 - Accepted: 28 July 2014 - Published: 3 September 2014

\begin{abstract}
The main objective of this study was to assess the impact of biochar rate $\left(0,8,16\right.$ and $\left.32 \mathrm{Mgha}^{-1}\right)$ on the water retention capacity (WRC) of a sandy loam Dystric Plinthosol. The applied biochar was a by-product of slow pyrolysis $\left(\sim 450^{\circ} \mathrm{C}\right)$ of eucalyptus wood, milled to pass through a $2000 \mu \mathrm{m}$ sieve that resulted in a material with an intrinsic porosity $\leq 10 \mu \mathrm{m}$ and a specific surface area of $\sim 3.2 \mathrm{~m}^{2} \mathrm{~g}^{-1}$. The biochar was incorporated into the top $15 \mathrm{~cm}$ of the soil under an aerobic rice system. Our study focused on both the effects on WRC and rice yields 2 and 3 years after its application. Undisturbed soil samples were collected from 16 plots in two soil layers (5-10 and 15$20 \mathrm{~cm}$ ). Soil water retention curves were modelled using a nonlinear mixed model which appropriately accounts for uncertainties inherent of spatial variability and repeated measurements taken within a specific soil sample. We found an increase in plant-available water in the upper soil layer proportional to the rate of biochar, with about $0.8 \%$ for each $\mathrm{Mg} \mathrm{ha}^{-1}$ biochar amendment 2 and 3 years after its application. The impact of biochar on soil WRC was most likely related to an effect in overall porosity of the sandy loam soil, which was evident from an increase in saturated soil moisture and macro porosity with 0.5 and $1.6 \%$ for each $\mathrm{Mg} \mathrm{ha}^{-1}$ of biochar applied, respectively. The increment in soil WRC did not translate into an increase in rice yield, essentially because in both seasons the amount of rainfall during the crit-
\end{abstract}

ical period for rice production exceeded $650 \mathrm{~mm}$. The use of biochar as a soil amendment can be a worthy strategy to guarantee yield stability under short-term water-limited conditions. Our findings raise the importance of assessing the feasibility of very high application rates of biochar and the inclusion of a detailed analysis of its physical and chemical properties as part of future investigations.

\section{Introduction}

Soil water retention capacity (WRC) is a potential indicator of soil quality and productivity. Several agronomic practices such as no-tillage, mulching and cover crops are implemented aiming to improve soil physical properties. An enhanced soil WRC through the adoption of these practices is attained via protection of the soil surface, improved soil aeration and infiltration, or an increased soil organic matter level. Of particular relevance for protection of soil surface, the use of mulching is regarded as an effective option (Fernández et al., 2012; Lee et al., 2013; Prats et al., 2013). However, according to Mcdonagh et al. (2014), improved soil management practices likely to be adopted by land users are multi-purpose technologies. In this context, the use of carbonised biomass, or biochar, has been regarded as 
an interesting option for improving soil physical properties (Glaser et al., 2002).

The rising demand for charcoal by iron smelters in Brazil has resulted in a rapid increase in the area covered with timber plantations. Between 2005 and 2010 the total increase was $23 \%$. In 2010, forest plantations in Brazil covered 6 million hectares of which $73 \%$ was comprised of eucalyptus forests. In comparison to natural vegetation, land use for eucalyptus plantations might not have a negative impact on soil organic carbon content (Fialho and Zinn, 2012). In contrast, the cutting of native vegetation for charcoal production can result in highly degraded land, due to a drastic decrease in soil organic matter content and increase in soil bulk density (Araújo et al., 2013). Of all produced wood in Brazil, around $35 \%$ was destined to charcoal production (ABRAF, 2010). Small pieces of char $(<8 \mathrm{~mm})$ have to be compacted into bricks if they are to be used as charcoal by iron smelters. Alternatively, these pieces can be recycled as soil amendment. Potentially, a large quantity of this type of biochar is available for Brazilian farmers. It is this material that was tested in the current study.

Tryon (1948) showed that available soil moisture in a sandy soil increased linearly with increasing wood biochar application rate. Several recent studies have also reported the potential of wood biochar to increase the WRC of sandy soils (Pereira et al., 2012; Dempster et al., 2012; Basso et al., 2013; Abel et al., 2013; Ibrahim et al., 2013). The majority of studies were conducted under artificially controlled conditions, testing the effect of a wide range of biochar amounts on WRC. Though such studies are useful, the extrapolation of their results to field conditions present some limitations: (i) the amounts of biochar tested are often larger than what is practically and economically feasible for incorporation into agricultural fields; (ii) the conditions for biochar application in artificially packed soil samples might lead to artefacts not normally encountered under field conditions, where biochar is incorporated via tillage and crops are grown afterwards; and (iii) the consolidation time is usually shorter in artificially controlled conditions than under field trials. Thus, more long-term studies on the effect of biochar under field conditions are required.

The increment in available water following biochar application is commonly related to the porous structure of the material. The pores behave as additional capillaries, favouring the WRC of the soil. Primarily, the number and size of pores is determined by the type of feedstock, temperature level and time of pyrolysis. The specific surface area (SSA) of biochar increases with temperature of pyrolysis (Lei and Zhang, 2013; Bornemann et al., 2007). At temperatures of $450^{\circ} \mathrm{C}$ the SSA can be smaller than $10 \mathrm{~m}^{2} \mathrm{~g}^{-1}$, while at temperatures of $600-750^{\circ} \mathrm{C}$ it can rise to around $400 \mathrm{~m}^{2} \mathrm{~g}^{-1}$ (Kookana et al., 2011). Clearly, SSA is a characteristic that should be considered when the impact of biochar on soil WRC is investigated. Secondly, the particle size of biochar can be a determinant of the potential positive effect on soil
WRC. Tryon (1948) showed that the impact on soil WRC was higher with finer material $(<1000 \mu \mathrm{m})$ than with larger particle sized biochar $(2000-5000 \mu \mathrm{m})$.

The soil WRC is represented by the nonlinear relation between volumetric soil moisture and matric potential, referred to as the soil water retention curve (SWRC). Such curves can be used as indicators of changes in soil physical properties caused by the incorporation of biochar into the soil matrix. The van Genuchten model (van Genuchten, 1980) is one of the most widely used representations of the soil WRC. Generally, statistical programs specifically designed to fit SWRC only allow the fitting of curves for isolated treatments, without accounting for experimental structure (e.g. Dourado-Neto et al., 2000). The isolated treatment-specific model fitting has three main disadvantages: (i) comparison of SWRC between treatments via formal statistical tests is not possible due to the absence of an error structure that accounts for overall variance within treatments; (ii) autocorrelations among random errors of moisture measurements taken in the same sample unit (the cylinder) under different matric potentials are ignored, leading to incorrect quantification of model uncertainty; and (iii) the spatial variability, likely to be high under field conditions, cannot be fully accounted for (Omuto et al., 2006). In this study we propose the use of a nonlinear mixed (NLM) model to overcome these disadvantages.

Circa $40 \%$ of overall Brazilian crop production is located in the Brazilian Midwest region (IBGE, 2012), where our study was conducted. The predominant biome in this region is a tropical savannah. Although a tropical savannah is a drought-prone environment (Peel et al., 2007), Brazilian farmers usually manage to grow two crops during the wet season (from October to March). However, rising temperatures and changes in rainfall distribution pattern have decreased the chances of an economically successful second harvest. Further temperature rises are projected to provoke decreases in suitable area for cultivation of the majority of crops in Brazil, mainly due to an increase in evapotranspiration (Assad et al., 2008). This further stresses the need of agronomic measures able to increase the water use efficiency in crop production.

The current study is a continuation of the experiment described by Petter et al. (2012), in which they showed that rice yields increased with around $3 \%$ per $\mathrm{Mg} \mathrm{ha}^{-1}$ biochar amendment in the first and second seasons after application. Additionally, in a pot experiment using a sterile sand, Pereira et al. (2012) observed an increase in soil WRC at matric potentials lower than $-6 \mathrm{kPa}$ with a rate of $12 \% \mathrm{w} / \mathrm{w}$ of a similar biochar as the one tested in this study, accompanied by a delay in the point where rice transpiration rate is affected by water stress and declines. Hence, the main objective of this study was to test the impact of a range of wood biochar rates (up to $1.5 \% \mathrm{w} / \mathrm{w}$ ) on both soil WRC and rice yields on a sandy loam Dystric Plinthosol at 2 and 3 years after application under field conditions. As part of this endeavour, 
we introduce the use of a NLM model for estimating shape parameters of the SWRCs.

\section{Material and methods}

\subsection{Experimental setup and biochar characterisation}

In 2008, a permanent non-irrigated field trial was set up at Estrela do Sul Farm in Nova Xavantina, Mato Grosso, in the Brazilian Midwest region $\left(14^{\circ} 34^{\prime} 50^{\prime \prime} \mathrm{S}\right.$ and $\left.52^{\circ} 24^{\prime} 01^{\prime \prime} \mathrm{W}\right)$ on sandy loam Dystric Plinthosol (76\% sand, $17 \%$ clay). The Köpper-Geiger climate classification of the region is Aw (Peel et al., 2007). The monthly precipitation and average temperatures since the start of the field trial are presented in Fig. 1, based on data from Agritempo (2014). Details of the history of the field trial and soil chemical properties can be found in Petter et al. (2012), who reported on the influence of biochar application on rice growth and yields at 1 month and at 1 year after application. Here we report on the most recent growing seasons of rice: from 13 December 2010 to 2 April 2011, and from 13 December 2011 to 2 April 2012, corresponding to 2 (S2) and 3 (S3) years after biochar application, respectively. Our analysis focuses on the influence of biochar on two variables, namely soil WRC and rice yields. Biochar was applied once, when the field trial was established on 5 December, 2008. Four levels of mineral fertilisation were applied in strips, and the four levels of biochar $\left(0,8,16\right.$ and $\left.32 \mathrm{Mg} \mathrm{ha}^{-1}\right)$ where applied within the strips in a randomised block design, with four replicates. Sixteen treatments were used, resulting in a total of 64 experimental plots, each with an area of $40 \mathrm{~m}^{2}(4 \times 10 \mathrm{~m})$. Mineral fertilisation was always applied in strips across the four blocks. In $\mathrm{S} 2$ and $\mathrm{S} 3$, four levels of $\mathrm{N}$-fertilisation $(0,30$, 60 and $90 \mathrm{~kg} \mathrm{Nha}^{-1}$ ) were applied and all plots were given the same rate of $\mathrm{P}-\mathrm{K}\left(\mathrm{kg} \mathrm{ha}^{-1}\right)$ at sowing (60-20 in S2, and 30-30 in S3) taking into account the soil chemical analysis prior to sowing and fertiliser recommendations for aerobic rice systems in the Brazilian savannah (EMBRAPA, 2007). The N-fertiliser (urea) was divided into three applications: at sowing and at 25 and 45 days after emergence (DAE). Rice (BRS Primavera) was sown directly with a five-row Semeato ${ }^{\circledR}$ planter adapted for no-tillage systems, with space between rows of $45 \mathrm{~cm}$ and 110 seeds $\mathrm{m}^{-1}$. Weeds infestation was chemically controlled with Glyphosate ${ }^{\circledR}\left(5 \mathrm{~L} \mathrm{ha}^{-1}\right)$ applied at around 15 days prior to sowing and with 2-4 D $\left(0.7 \mathrm{~L} \mathrm{ha}^{-1}\right)$ or Star Rice ${ }^{\circledR}\left(0.4 \mathrm{~L} \mathrm{ha}^{-1}\right)$ around $10 \mathrm{DAE}$. Additionally, manual weeding operations were conducted at around 45 and 75 DAE.

Air-dried biochar (particle size $\leq 2000 \mu \mathrm{m}$ ) was spread manually on the soil surface, and incorporated into the upper $15 \mathrm{~cm}$, using a harrow. The amount of biochar applied to the upper $15 \mathrm{~cm}$ was based on the average amount of pyrogenic $\mathrm{C}$ found in the fertile anthropogenic dark earths (ADE) of the Amazon. According to Glaser et al. (2001) the up- per $30 \mathrm{~cm}$ of the ADE soils contain around $25 \mathrm{Mg} \mathrm{ha}^{-1}$ pyrogenic $\mathrm{C}$, corresponding to an amount of $12.5 \mathrm{Mg} \mathrm{ha}^{-1}$ within $0-15 \mathrm{~cm}$ soil layer. As the biochar tested in our field trial had a concentration of $77 \%$ pyrogenic $\mathrm{C}$, we applied a lower $\left(8 \mathrm{Mg} \mathrm{ha}^{-1}\right)$, similar $\left(16 \mathrm{Mg} \mathrm{ha}^{-1}\right)$ and higher $\left(32 \mathrm{Mg} \mathrm{ha}^{-1}\right)$ rate of biochar than the amount of pyrogenic $\mathrm{C}$ found in ADE. Considering the soil bulk density and depth where biochar was applied, the application rate on a dry mass basis (weight of biochar/total weight of soil), was equivalent to 0.4 , 0.7 and $1.5 \% \mathrm{w} / \mathrm{w}$. The biochar was made of eucalyptus timber via slow pyrolysis in a cylindrical metal kiln using temperatures around $400-500^{\circ} \mathrm{C}$. A single-point surface area of biochar was determined by the Brunauer, Emmelet and Teller (BET) nitrogen absorption method (Brunauer et al., 1938), using nitrogen gas sorption analysis at $77.3 \mathrm{~K}\left(-195.9^{\circ} \mathrm{C}\right)$. The SSA of the biochar applied, with a bulk density of $0.3 \mathrm{~g} \mathrm{~cm}^{-3}$, was $3.2 \pm 0.5 \mathrm{~m}^{2} \mathrm{~g}^{-1}$. The porous structure of the biochar (pore size $\leq 10 \mu \mathrm{m}$ ) is shown in Fig. 2. The high-resolution images were made using a Scanning Electron Microscope (SEM), Jeol, JSM-6610, equipped with EDS, Thermo Scientific NSS Spectral Imaging. The samples were covered with a gold film before analysis with the equipment Denton Vacuum, Desk V. Chemical properties of the biochar are described in Petter et al. (2012).

\subsection{Measurements on soil WRC and the modelling of SWRCs}

The soil WRC was evaluated at 2 (S2) and 3 (S3) years after biochar application. Soil samples (cylinders of inox steel of $5 \mathrm{~cm}$ height and $5 \mathrm{~cm}$ diameter) were collected from minitrenches $50 \mathrm{~cm}$ deep between rows of rice around $75 \mathrm{DAE}$. Setting of mini-trenches was completely randomised among two strips located at the right and left borders of the field trial (two replicates for each biochar rate within each strip). Since the biochar was incorporated into the upper $15 \mathrm{~cm}$ layer, soil samples were collected in the centre $(5-10 \mathrm{~cm})$ and just below $(15-20 \mathrm{~cm})$ this layer to account for an effect of biochar that had possibly moved out of the original layer. Samples were collected from 16 plots (4 biochar rates $\times 4$ plots, one sample per soil layer per plot) in a moist soil on 15 March 2011 and on 3 March 2012. The soil WRC was determined according to EMBRAPA (1997) adapted from Freitas Jr. and Silva (1984). Samples were saturated with water for $12 \mathrm{~h}$ and analysed in a centrifuge Kokusan $\mathrm{H}-1400 \mathrm{pF}^{\circledR}$, four samples at a time, for $30 \mathrm{~min}$ under seven speed levels: $600,700,800,1300,1800,2400$ and $9100 \mathrm{rpm}$ (equivalent to $0,33.00,44.92,58.67,154.93,297.03$ and $528.05 \mathrm{~g}$ ). The volume of the soil water in the samples subjected to different speeds corresponded to seven matric potentials: -6 , $-8,-10,-33,-60,-100$ and $-1500 \mathrm{kPa}$. The bulk density was determined as the ratio between the dried mass of soil and the volume of a cylinder. The bulk density was used to calculate the volumetric soil moisture $\left(\mathrm{cm}^{3} \mathrm{~cm}^{-3}\right)$. Saturated soil moisture was determined as the soil moisture content in 


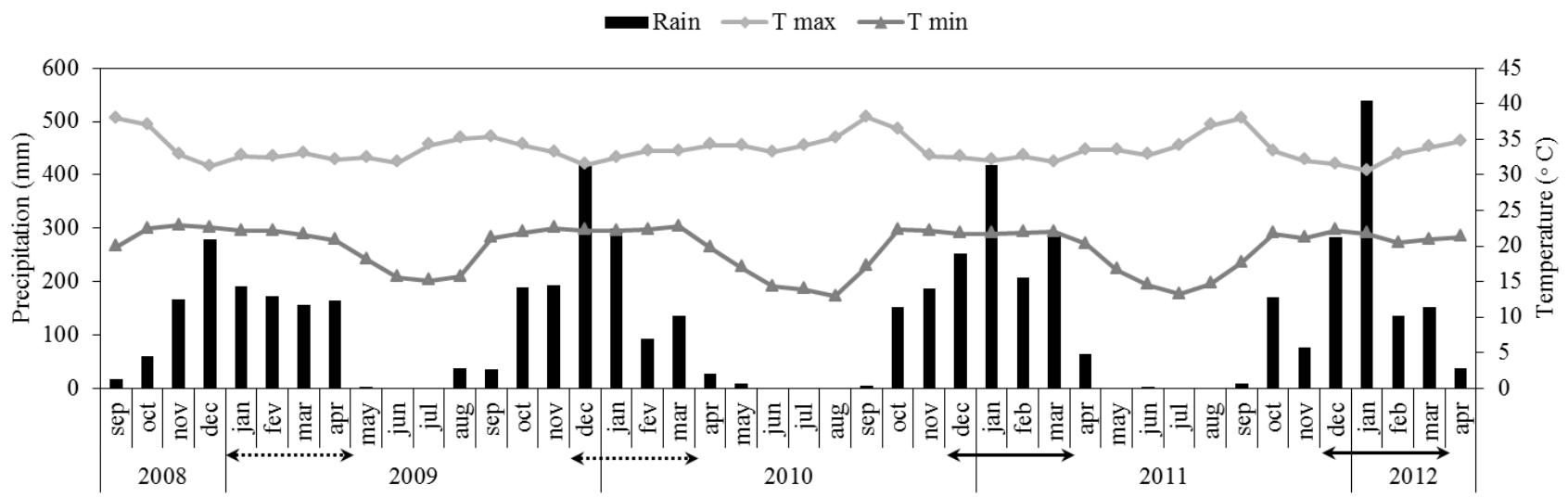

Figure 1. Monthly precipitation (Rain) and average of maxima ( $T$ max) and minima ( $T$ min) temperatures since application of biochar in the field trial in Nova Xavantina, MT, Brazil. Solid arrows indicate rice-growing seasons S2 and S3. Dotted arrows represent previous seasons reported by Petter et al. (2012).

saturated samples at $0 \mathrm{kPa}$ right before subjecting samples to different speeds in the centrifuge.

The relation between observed volumetric soil moisture and soil matric potential (the SWRC) was determined by fitting the van Genuchten model described in Eq. (1).

$\theta(\psi)=\theta_{\mathrm{r}}+\left(\theta_{\mathrm{s}}-\theta_{\mathrm{r}}\right) \cdot\left[\frac{1}{1+(\alpha \psi)^{n}}\right]^{m}$,

where $\theta(\Psi)$ is the volumetric soil moisture $\left(\mathrm{cm}^{3} \mathrm{~cm}^{-3}\right)$ at a given matric potential $\Psi(\mathrm{kPa}), \theta_{\mathrm{r}}$ is the residual soil moisture (soil moisture content at a $\Psi \geq-1500 \mathrm{kPa}$ ), $\theta_{\mathrm{s}}$ is the saturated soil moisture (soil moisture content at $0 \mathrm{kPa}$ ) and $m, \alpha$ and $n$ are shape parameters. The Mualem constraint $m=1-1 / n$ (Mualem, 1976) was adopted to increase model parsimony.

We used a NLM model for uncertainty assessment of SWRC estimates by considering the whole experimental design structure to quantify residual variance. For parsimony and to reduce the risk of non-convergence, we set $\theta_{\mathrm{r}}$ and $\theta_{\mathrm{s}}$ as known parameters. By adopting such an approach, the quantification of uncertainty of shape parameters $\alpha$ and $n$ and the test of the null hypothesis of interest were performed considering the overall variance of soil moisture arising from within treatments variance. Further, the NLM model permits accounting for potential random effects associated with plot location, as proposed by Omuto et al. (2006). In our study, correlations among measurements taken within the same sample unit (one cylinder per plot for each soil depth) were accounted for by including plot as a random effect $u$ in the model. The core of the NLM model adopted is the van Genuchten-Mualem model (Eq. 1). The generic NLM model used to estimate the SWRC for each biochar level within two soil layers and 2 years is given by
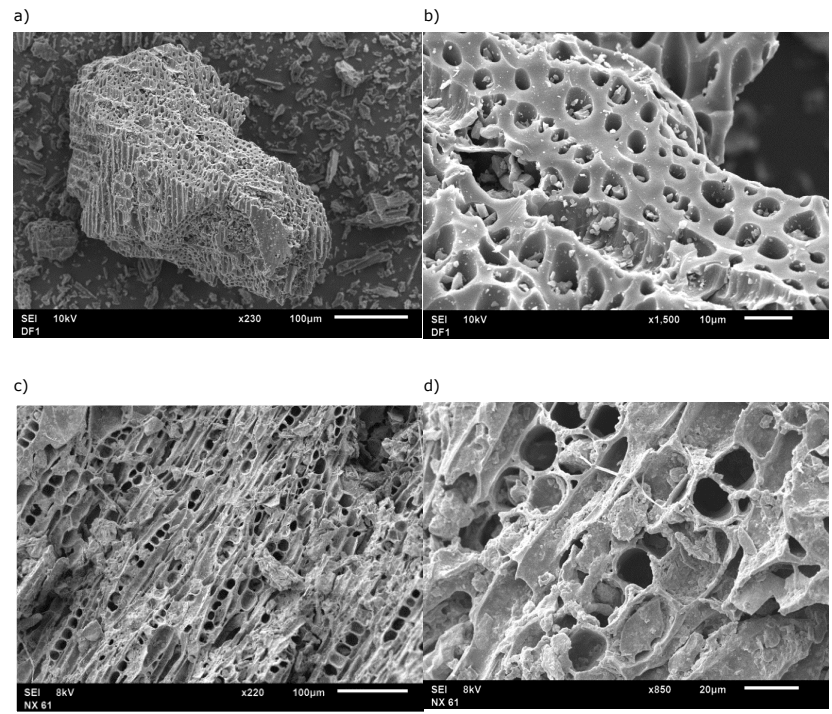

Figure 2. High-resolution images of Eucalyptus wood biochar (particle size $\leq 2000 \mu \mathrm{m}$ ) before application $(\mathbf{a}, \mathbf{b})$ and 2 years after application into a sandy Dystric Plinthosol (c, d). Images made at LABMIC, Institute of Physics, Federal University of Goiás.

$$
\begin{aligned}
Y_{i j k} & =\bar{\theta}_{\mathrm{r}(i)}+\left(\bar{\theta}_{\mathrm{s}(i)}-\bar{\theta}_{\mathrm{r}(i)}\right) \cdot\left[\frac{1}{1+\left(\alpha_{i} \psi_{i j k}\right)^{n_{i}}}\right]^{1-1 / n_{i}} \\
& +u_{i j}+e_{i j k},
\end{aligned}
$$

where $Y_{i j k}$ is the observed soil moisture of the treatment level $i\left(i=0,8,16,32 \mathrm{Mg} \mathrm{ha}^{-1}\right)$ in the replication $j(j=1,2$, $3,4)$ at a matric potential $k(k=-6,-8,-10,-33,-60$, $-100 \mathrm{kPa}) ; \bar{\theta}_{\mathrm{r}(i)}$ is the residual soil moisture in the treatment level $i$, averaged over observed values $\theta_{\mathrm{r}(i j)}$ in $j$ replicates; $\bar{\theta}_{\mathrm{s}(i)}$ is the saturated soil moisture in the treatment level $i$ averaged over observed values $\theta_{\mathrm{s}(i j)}$ in $j$ replicates; 
$\alpha_{i}$ and $n_{i}$ are the shape parameters for each treatment level $i ; u_{i j} \sim \mathrm{N}(0, \Sigma)$ represents the random effect of latent variables associated with location of a plot $i j(i j=1, \ldots, 16)$; and $e_{i j k} \sim \mathrm{N}\left(0, \sigma^{2}\right)$ is the random error associated with each measurement $Y_{i j k}$. The residual soil moisture $\left(\theta_{\mathrm{r}(i j)}\right)$ was assumed as the measured soil moisture content at $-1500 \mathrm{kPa}$ and the saturated soil moisture $\left(\theta_{\mathrm{s}(i j)}\right)$ as the measured soil moisture content at $0 \mathrm{kPa}$. Shape parameters were estimated using the maximum likelihood method, implemented in the NLMIXED procedure of the SAS/STAT ${ }^{\circledR}$ software (SAS Institute Inc., 2008). Comparisons of shape parameters between control and treatments with biochar were performed by $t$ tests for linear contrasts.

\subsection{Analysis of soil physical-hydric variables response to biochar rate}

The response of some key soil physical-hydric variables to biochar rate was evaluated via measurements of: (i) soil bulk density (BD); (ii) saturated soil moisture $\left(\theta_{s}\right)$; (iii) residual soil moisture $\left(\theta_{\mathrm{r}}\right)$; (iv) macro porosity (MAC), as the predicted soil moisture content between 0 and $-6 \mathrm{kPa}\left(\hat{\theta}_{0}-\hat{\theta}_{6}\right)$; (v) rice available water (RAW), as the predicted soil moisture content between -6 and $-100 \mathrm{kPa}\left(\hat{\theta}_{6}-\hat{\theta}_{100}\right)$; and (vi) plantavailable water (PAW) as the predicted soil moisture content between -6 and $-1500 \mathrm{kPa}\left(\hat{\theta}_{6}-\hat{\theta}_{1500}\right)$. The predicted volumetric soil moisture $(\hat{\theta})$ was estimated via the model described in Eq. (2). The RAW was also estimated considering that the critical soil water volume for rice production should be defined at a matric potential of $-100 \mathrm{kPa}$ as according to Wopereis et al. (1996).

Response of physical-hydric soil variables to biochar rate were analysed for each year and soil layer separately via the quadratic model

$y_{i j}=\beta_{0}+\beta_{1} \operatorname{char}_{i}+\beta_{2} \operatorname{char}_{i}^{2}+e_{i j}$,

where $y_{i j}$ is the observation of the response variable $y$ corresponding to biochar level $i\left(i=0,8,16,32 \mathrm{Mgha}^{-1}\right)$ of the replication $j(j=1,2,3,4) ; \beta_{0}$ is the intercept; $\beta_{1}$ and $\beta_{2}$ are the linear and quadratic effects of biochar, respectively; and $e_{i j} \sim \mathrm{N}\left(0, \sigma^{2}\right)$ is the random error associated with each observation $y_{i j}$.

Analyses were performed using the MIXED procedure (Proc MIXED) of the statistical software SAS/STAT ${ }^{\circledR}$ (SAS Institute Inc., 2008). The magnitude of the biochar effect was assessed by nominal significance levels ( $p$ values) derived from hypothesis testing of $\beta_{1}$ and $\beta_{2}$ estimates. Due to the large experimental area, relatively high residual variances were anticipated to occur. For that reason, we adopted 0.10 as the appropriate $p$ value for the selection of model predictors in order to safeguard against high type II error.

\subsection{Measurement and analysis of rice yield and yield components}

The response of rice yield and yield components was measured for all biochar and $\mathrm{N}$-fertilisation treatments. At crop maturity, around $100 \mathrm{DAE}$, total shoot dry matter, grain yield (weight of rice grains dried to $13 \%$ moisture) and yield components (number of panicles, grains panicle ${ }^{-1}$, grain filling index and 1000-grain weight) were determined in samples collected from two rows of $3 \mathrm{~m}$ in the centre of each plot. Harvest index was calculated as the ratio between grain yield and total shoot dry matter. Filled and unfilled grains from panicles within the harvested area were separated with a vertical blower and counted with a seed counter. Grain filling index was calculated as the ratio between the number of filled grains and the total number of grains.

We used a linear mixed model instead of the commonly used design-based analysis of variance to analyse the data due the incomplete randomisation of $\mathrm{N}$ treatments. The linear mixed model adopted allowed us to account for potential spatial auto-correlation among plot measurements. Location of a plot was established by its position in a specific block and row within a block. The location of a plot was included as a random effect. Biochar, $\mathrm{N}$, biochar $\times \mathrm{N}$ and quadratic terms were included as fixed effects. Model parameters were estimated by the restricted maximum likelihood method REML. Analyses were performed using the Mixed procedure (Proc MIXED) of the statistical software SAS/STAT ${ }^{\circledR}$ (SAS Institute Inc., 2008). Graphical residual analysis, influence diagnostics and checking for potential violation of model assumption were conducted using the ODS GRAPHICS option. Response surfaces for identifying patterns of response of rice yields and yield components to biochar and $\mathrm{N}$ treatments were modelled for each season separately. A complete quadratic model (Eq. 4) in which all predictors (biochar, $\mathrm{N}$ and biochar $\times \mathrm{N}$ ) were included was the starting point:

$$
\begin{aligned}
y_{i j b r} & =\beta_{0}+\beta_{1} \operatorname{char}_{i}+\beta_{2} N_{i}+\beta_{3} \operatorname{char}_{i} \times N_{i}+\beta_{4} \operatorname{char}_{i}^{2} \\
& +\beta_{5} N_{i}^{2}+c_{b}+d_{r}+e_{i j b r},
\end{aligned}
$$

where $y_{i j b r}$ is the observation of the response variable $y$ corresponding to biochar and $\mathrm{N}$ treatments $i(i=1,2,3,4$, $\ldots, 16)$ of the replication $j(j=1,2,3,4) ; \beta_{0}$ is the intercept; $\beta_{1}$ and $\beta_{2}$ are linear effects of biochar and $\mathrm{N}$, respectively; $\beta_{3}$ is the interaction effect biochar $\times \mathrm{N} ; \beta_{4}$ and $\beta_{5}$ are quadratic effects of biochar and $\mathrm{N}$, respectively; $c_{b}$ and $d_{r} \sim \mathrm{N}(0, \Sigma)$ are the potential random effects related to location of a plot in a block $b(b=1,2,3,4)$ and in a row $r(r=1,2,3,4)$ within a block $b$; and $e_{i j b r} \sim \mathrm{N}\left(0, \sigma^{2}\right)$, the random error associated with each observation $y_{i j b r}$.

Again, we adopted 0.10 as the appropriate $p$ level in the process of predictors' selection. To determine the appropriate response surface, predictors containing the highest $p$ value $(p>0.10)$ were progressively excluded respecting the hierarchy of effects: linear terms were retained whenever 
interaction or quadratic terms were significant (MacCullagh and Nelder, 1983). The magnitude and evidence of the effects were assessed by estimates and their respective nominal significance levels.

\section{Results}

\subsection{The use of NLM to adjust SWRCs and effects of biochar rate on shape parameters}

Overall, the goodness of fit was high $\left(R^{2}: 0.77\right.$ to 0.98$)$, indicating the adequacy of the proposed NLM model to estimate the shape parameters of the SWRCs (Table 1). Inclusion of the random effect $u$ significantly increased the accuracy of the SWRC modelling (Fig. 3). The consistent SWRC underestimation at high matric potential was likely due to increases in soil moisture content with biochar application, which was particularly evident from SWRCs for treatments with 8 and $32 \mathrm{Mg} \mathrm{ha}^{-1}$ in the upper and lower soil layers in S2.

The evidence of the effects of biochar on shape parameters can be seen through changes in patterns of the SWRCs. At 2 years after biochar application in both soil layers for the treatment with $8 \mathrm{Mg} \mathrm{ha}^{-1}$ the shape parameters $\alpha$ and $n$ were significantly lower and higher than control, respectively (Table 1). Also in S2, in the upper layer $5-10 \mathrm{~cm}$, for the treatment with $32 \mathrm{Mg} \mathrm{ha}^{-1}$ the parameter $\alpha$ was lower $(p \leq 0.10)$ than the control. The SWRCs in the upper layer for the treatment with 8 and $32 \mathrm{Mg} \mathrm{ha}^{-1}$ were above that of the control treatment at matric potentials between $-0.03 \mathrm{kPa}$ and $-33 \mathrm{kPa}$ (Fig. 4). In S2, the most significant difference $(p \leq 0.05)$ was for the parameter $n$ of the treatment with $8 \mathrm{Mg} \mathrm{ha}^{-1}$ in the lower soil layer $15-20 \mathrm{~cm}$. The SWRC in the lower layer for the treatment with $8 \mathrm{Mg} \mathrm{ha}^{-1}$ was above that of control at matric potentials between -1 and $-10 \mathrm{kPa}$.

In S3, no significant effects of biochar amendment on shape parameters were observed. In the upper layer, the SWRCs of the treatments with biochar amendment were all above the SWRC of the control treatment at matric potentials higher than $-1 \mathrm{kPa}$, whereas at matric potentials lower than $-10 \mathrm{kPa}$, the soil moisture content dropped abruptly to below that of the control treatment. This was particularly evident with $32 \mathrm{Mg} \mathrm{ha}^{-1}$. In S3, in the lower soil layer, the same pattern was observed, but in this layer soil moisture content for treatments with biochar dropped under matric potential lower than $-6 \mathrm{kPa}$, except for the SWRC of the highest biochar treatment $\left(32 \mathrm{Mg} \mathrm{ha}^{-1}\right)$, which was now slightly below that of the control treatment already under matric potential higher than $-1 \mathrm{kPa}$.

\subsection{Response of soil physical-hydric variables to biochar application rate}

Most significant responses to biochar application rate were observed in the upper soil layer $(5-10 \mathrm{~cm})$, with minor responses in the lower soil layer $(15-20 \mathrm{~cm}$; Table 2$)$. In the up- per layer, RAW and PAW increased linearly with biochar application rate. The increment in RAW and PAW was around 1 and $0.8 \%$ for each $\mathrm{Mg} \mathrm{ha}^{-1}$ of biochar applied or 21 and $17 \%$ with $1 \% \mathrm{w} / \mathrm{w}$ rate of biochar amendment, respectively. The response of RAW and PAW to biochar rate was stronger in $\mathrm{S} 3(p \leq 0.05)$ than in $\mathrm{S} 2(p \leq 0.10)$, with narrower confidence intervals in S3 (Fig. 5).

In $\mathrm{S} 2$ in the lower layer only BD was significantly affected by biochar application. The response of $\mathrm{BD}$ (mean \pm standard error) to biochar rate followed a quadratic trend, with maximum at $16 \mathrm{Mg} \mathrm{ha}^{-1}(1.684 \pm 0.013)$ and a minimum at control $(1.639 \pm 0.015)$. In $\mathrm{S} 3$, in the upper layer, saturated soil moisture $\left(\theta_{\mathrm{S}}\right)$ and MAC increased linearly $(p \leq 0.05)$ with 0.5 and $1.6 \%$ for each $\mathrm{Mg} \mathrm{ha}^{-1}$ of biochar applied, respectively; whereas in the lower layer only MAC was significantly affected by biochar application. The response of MAC to biochar rate in the lower layer followed a quadratic pattern with maximum at $16 \mathrm{Mg} \mathrm{ha}^{-1}(0.2299 \pm 0.0152)$ and minimum at $32 \mathrm{Mg} \mathrm{ha}^{-1}$ $(0.1744 \pm 0.0184)$.

\subsection{Response of rice yields and yield components to biochar and $\mathbf{N}$ application rate}

There was no response of rice yields to biochar application rate in either season (Table 3). In S2, total shoot dry matter (TDM) and grain yield (GY) were not affected by biochar or $\mathrm{N}$ application rate. Both TDM and GY varied greatly, from 0.57 and $0.17 \mathrm{Mg} \mathrm{ha}^{-1}$ (with $32 \mathrm{Mg} \mathrm{ha}^{-1}$ and without $\mathrm{N}$ ) to 4.04 and $1.99 \mathrm{Mg} \mathrm{ha}^{-1}$ (with $32 \mathrm{Mg} \mathrm{ha}^{-1}$ and $90 \mathrm{~kg} \mathrm{Nha}^{-1}$ ), respectively. Most significant $(p \leq 0.05)$ effects of biochar were observed on number of grains panicle ${ }^{-1}$ (GP) and grain filling index (GFI). The response of GP and GFI to biochar rate followed a quadratic pattern with a minimum obtained at about $16 \mathrm{Mg} \mathrm{ha}^{-1}$. The response of harvest index (HI) and number of panicles $\mathrm{m}^{-2}$ (PAN) to $\mathrm{N}$ rate followed a quadratic pattern with a maximum at around 30 to $60 \mathrm{~kg} \mathrm{~N} \mathrm{ha}^{-1}$. The estimated HI (mean \pm standard error) varied from a minimum at $0.42 \pm 0.02$ (with $90 \mathrm{~kg} \mathrm{Nha}^{-1}$ ) to a maximum at $0.53 \pm 0.02$ (with $30 \mathrm{~kg} \mathrm{~N} \mathrm{ha}^{-1}$ ) and PAN from $109 \pm 7$ (without $\mathrm{N}$ ) to $133 \pm 5$ (with $60 \mathrm{~kg} \mathrm{~N} \mathrm{ha}^{-1}$ ). The GFI and 1000-grain weight $(\mathrm{GW})$ decreased with increasing $\mathrm{N}$ rate.

A year later, in S3, the effect of biochar on any characteristic measured at crop maturity of rice was totally absent. The response of TDM and PAN to $\mathrm{N}$ rate followed a quadratic pattern with a maximum at 30 to $60 \mathrm{~kg} \mathrm{Nha}^{-1}$, whereas GY and GFI increased linearly with increasing $\mathrm{N}$ rate. Estimated GY increased from $0.49 \pm 0.2 \mathrm{Mg} \mathrm{ha}^{-1}$ (without $\mathrm{N}$ ) to $0.69 \pm 0.2 \mathrm{Mg} \mathrm{ha}^{-1}\left(90 \mathrm{~kg} \mathrm{Nha}^{-1}\right)$, regardless of biochar application (Table 3). The observed GY varied from 0.38 (with $8 \mathrm{Mg} \mathrm{ha}^{-1}$ and without $\mathrm{N}$ ) to $0.93 \mathrm{Mg} \mathrm{ha}^{-1}$ (with $16 \mathrm{Mg} \mathrm{ha}^{-1}$ and $60 \mathrm{~kg} \mathrm{Nha}^{-1}$ ). The HI and GP were not affected by $\mathrm{N}$ treatments, whereas GW decreased linearly $(p \leq 0.10)$ with increasing $\mathrm{N}$ rate. The GY in both seasons was rather low, 
a)

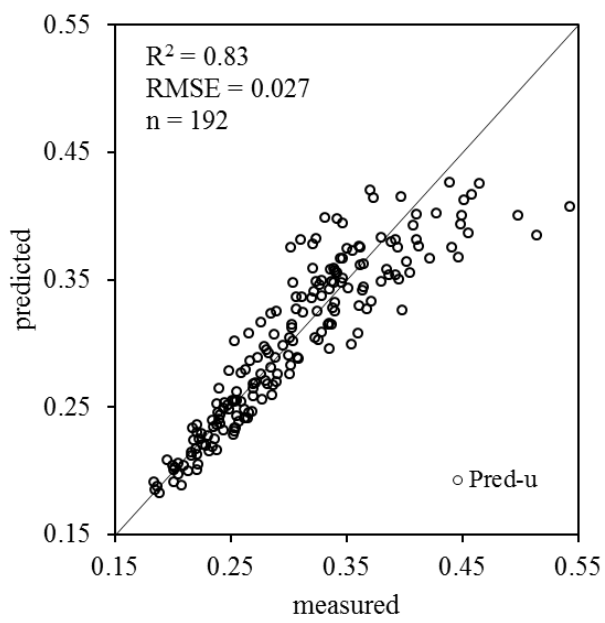

c)

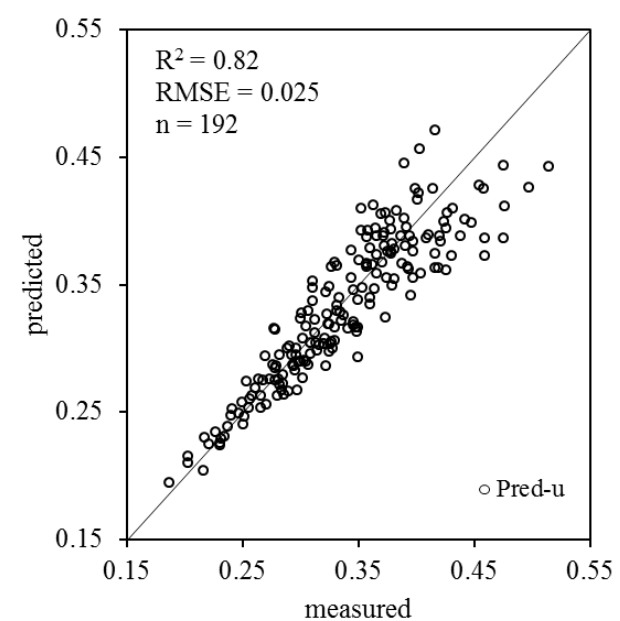

b)

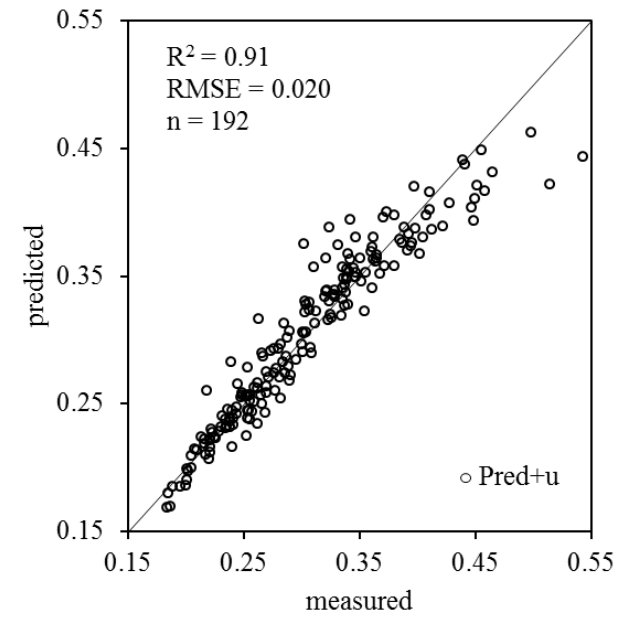

d)

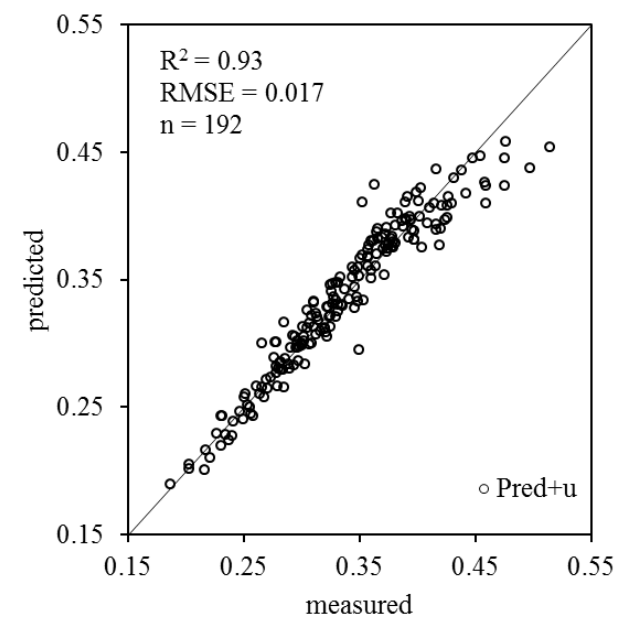

Figure 3. Goodness of fit of the NLM model used to predict soil water retention capacity, summarised via correlation coefficient $\left(R^{2}\right)$ and root mean square error (RMSE). Agreement between measured and predicted moisture values $(\mathbf{a}, \mathbf{c})$; agreement between measured and predicted moisture values including the random effect $u$ in the model $(\mathbf{b}, \mathbf{d})$. Data measured in 2 years and two soil layers: 5-10 $\mathrm{cm}(\mathbf{a}, \mathbf{b})$ and $15-20 \mathrm{~cm} \mathrm{(c,} \mathrm{d).}$

mainly due to weed infestations. Chemical and mechanical controls were applied when necessary, but these could not sufficiently compensate for the low resistance of the cultivar BRS Primavera to biotic stresses.

\section{Discussion}

Here we summarise and discuss the main findings of this study as follows: (i) the impact of the wood biochar application rate on WRC of the sandy loam Dystric Plinthosol is positive and persistent at 2 and 3 years after application; (ii) although soil WRC increases with biochar application rate, we did not observe any impact on rice yield; and (iii) the proposed nonlinear mixed (NLM) model was an innovative analytical tool for such a large field trial.

Our results showed that in both seasons PAW and RAW in the upper 5-10 cm layer of the sandy loam soil increased proportionally to biochar application rate with about 0.8 and $1 \%$ for each $\mathrm{Mg} \mathrm{ha}^{-1}$ of biochar applied, respectively (Fig. 5). The consistent increase in soil WRC seems to be related to a slight increase in soil moisture at $-6 \mathrm{kPa}$ for the treatment with $32 \mathrm{Mgha}^{-1}$, as can be observed by means of SWRCs in S2 and S3 (Fig. 4), with a significant effect on the shape parameter $\alpha$ in S2 (Table 1). In S2 we also observed significant changes in shape parameters of the SWRC with $8 \mathrm{Mg} \mathrm{ha}^{-1}$ (Table 1). However, there was no such effect for the treatment with $16 \mathrm{Mg} \mathrm{ha}^{-1}$, where the increase in soil 
a)

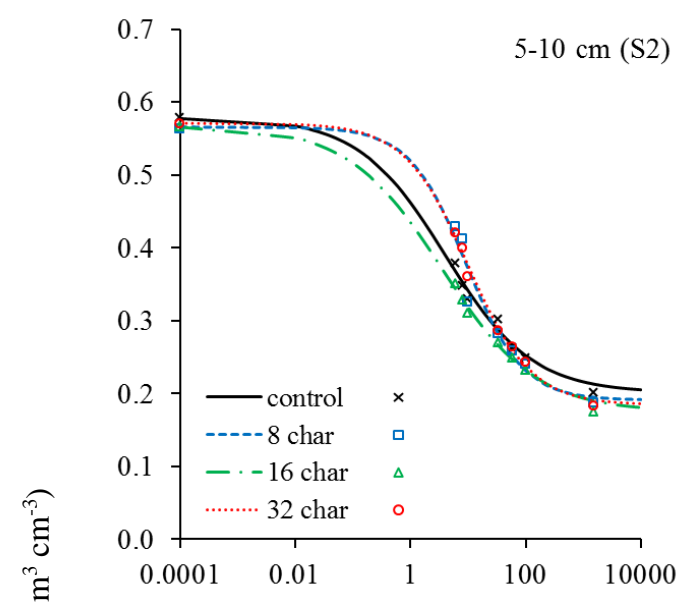

c)

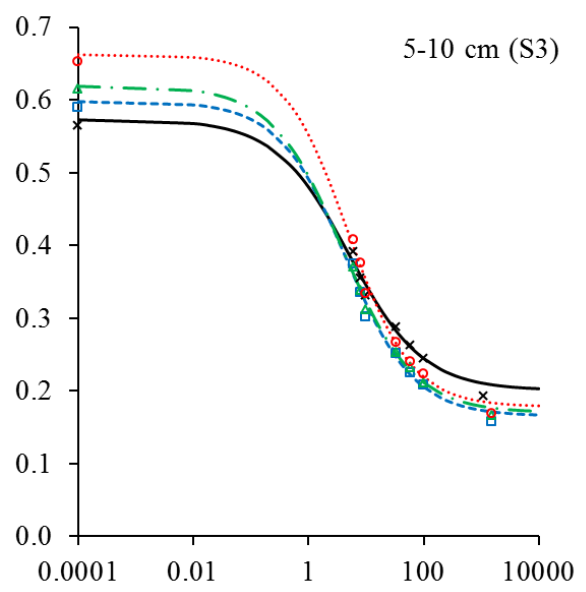

b)

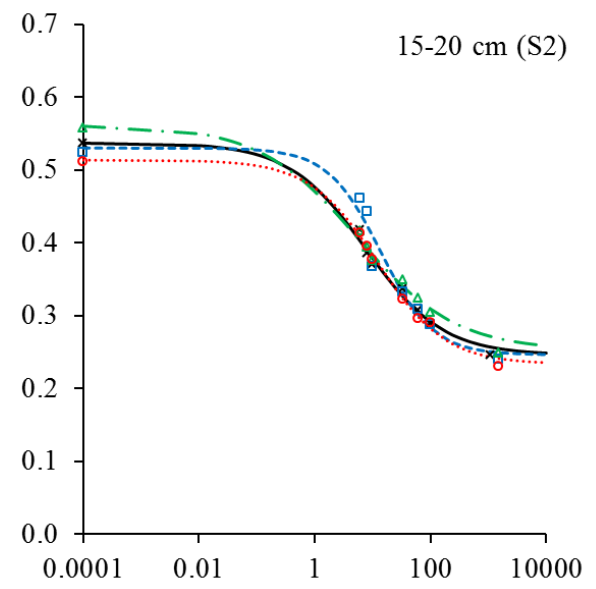

d)

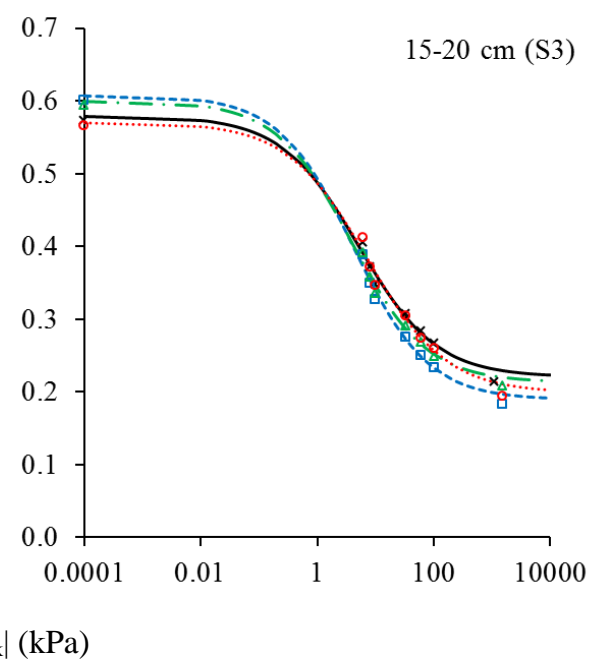

Figure 4. Predicted (lines) soil water retention curves and measured soil moisture (symbols) at a matric potential $k(k=0,-6,-8,-10$, $-33,-60,-100$ and $-1500 \mathrm{kPa}$ ) within 5-10 $\mathrm{cm}(\mathbf{a}, \mathbf{c})$ and $15-20 \mathrm{~cm}(\mathbf{b}, \mathbf{d})$ layers obtained at two (S2 - a, b) and three (S3 - c, d) years after application of biochar $\left(8,16\right.$ and $\left.32 \mathrm{Mg} \mathrm{ha}^{-1}\right)$ in a sandy Dystric Plinthosol. Estimates of shape parameters are presented in Table 1.

WRC seems to be a consequence of a decrease in soil moisture content with biochar rate up to $16 \mathrm{Mg} \mathrm{ha}^{-1}$ at matric potentials of $-100 \mathrm{kPa}(p \leq 0.13)$ and $-1500 \mathrm{kPa}(p \leq 0.16)$ in S2. The uncertainty of the linear response of PAW and RAW to biochar rate was higher in S2 than in S3, predominantly for rates of 8 and $16 \mathrm{Mg} \mathrm{ha}^{-1}$ (Fig. 5). The uncertainty can be related to changes in $\mathrm{BD}$ affecting the overall response to biochar application. In fact, BD was generally $1.7 \%$ higher in S2 than in S3 (Table 2), which was a consequence of mechanical weeding using a tractor which passed twice over all plots of the field trial just prior to sowing in S2. Even though we observed no effect of biochar rate on BD in the upper soil layer, in the lower soil layer 15-20 cm BD increased with biochar rate up to $16 \mathrm{Mg} \mathrm{ha}^{-1}$.
At matric potentials lower than $-8 \mathrm{kPa}$ the amount of water in soils treated with biochar decreased abruptly in both years while in $\mathrm{S} 3$ in the upper soil layer $\theta_{\mathrm{s}}$ and MAC increased significantly with increasing biochar rate (Table 2 ). It seems that biochar application led to an increase in soil moisture at a matric potential up to around -6 and $-8 \mathrm{kPa}$ that was not necessarily sustained under lower matric potentials (Fig. 4). Therefore, the effect of biochar on soil WRC is most likely a consequence of an effect in overall porosity of the soil. We found a notable increase in MAC of $51 \%$ with $1.5 \% \mathrm{w} / \mathrm{w}$ biochar amendment. The increase in MAC with biochar application rate was mostly related to the large particle size $(\leq 2000 \mu \mathrm{m})$ of the biochar tested. For instance, Abel et al. (2013) reported an increase of $15 \%$ in total porosity and $6 \%$ in air capacity with application of $5 \% \mathrm{w} / \mathrm{w}$ beech 
Table 1. Estimates of shape parameters of the van Genuchten model fitted to represent soil water retention within 5-10 $\mathrm{cm}$ and $15-20 \mathrm{~cm}$ layers at two (S2) and three (S3) years after application of 8,16 and $32 \mathrm{Mg} \mathrm{ha}^{-1}$ biochar into a sandy Dystric Plinthosol.

\begin{tabular}{|c|c|c|c|c|c|c|}
\hline \multirow[t]{2}{*}{ Treatment } & \multicolumn{2}{|c|}{ Parameter estimates $(5-10 \mathrm{~cm})$} & \multirow[t]{2}{*}{$R^{2}$} & \multicolumn{2}{|c|}{ Parameter estimates $(15-20 \mathrm{~cm})$} & \multirow[t]{2}{*}{$R^{2}$} \\
\hline & $\alpha$ & $n$ & & $\alpha$ & $n$ & \\
\hline & \multicolumn{6}{|c|}{$\mathrm{S} 2$} \\
\hline Control & $0.1110(0.0533)$ & $1.578(0.093)$ & 0.94 & $0.0344(0.0147)$ & $1.656(0.088)$ & 0.94 \\
\hline 8 & $0.0154 *(0.0052)$ & $1.882 *(0.110)$ & 0.83 & $0.0061 *(0.0023)$ & $1.951^{* *}(0.103)$ & 0.83 \\
\hline 16 & $0.1443(0.0725)$ & $1.533(0.088)$ & 0.95 & $0.0760(0.0371)$ & $1.513(0.075)$ & 0.89 \\
\hline \multirow[t]{2}{*}{32} & $0.0166^{*}(0.0056)$ & $1.794(0.089)$ & 0.77 & $0.0131(0.0055)$ & $1.741(0.087)$ & 0.82 \\
\hline & \multicolumn{6}{|c|}{ S3 } \\
\hline Control & $0.0651(0.0168)$ & $1.677(0.071)$ & 0.97 & $0.0661(0.0175)$ & $1.653(0.065)$ & 0.97 \\
\hline 8 & $0.0723(0.0150)$ & $1.738(0.081)$ & 0.95 & $0.0895(0.0196)$ & $1.678(0.067)$ & 0.97 \\
\hline 16 & $0.0969(0.0204)$ & $1.707(0.074)$ & 0.98 & $0.1049(0.0253)$ & $1.675(0.075)$ & 0.96 \\
\hline 32 & $0.0622(0.0110)$ & $1.781(0.078)$ & 0.97 & $0.0410(0.0113)$ & $1.636(0.052)$ & 0.94 \\
\hline
\end{tabular}

Standard error of estimates are within parentheses $(n=4)$. Nominal significance level of $t$ test for contrasts between control and treatments with biochar within season and soil layer: ${ }^{* *} p \leq 0.05$ and ${ }^{*} 0.05<p \leq 0.10 ; R^{2}$ : the squared Pearson correlation coefficient between measured and predicted soil moisture means $(n=24)$.

Table 2. Response of key physical hydric variables to biochar rate (char) at 2 (S2) and 3 (S3) years after application in a sandy Dystric Plinthosol soil.

\begin{tabular}{|c|c|c|c|c|}
\hline Variable & Fitted model $(5-10 \mathrm{~cm})$ & $R^{2}$ & Fitted model $(15-20 \mathrm{~cm})$ & $R^{2}$ \\
\hline & \multicolumn{4}{|c|}{ S2 } \\
\hline $\mathrm{BD}$ & 1.5923 & 0.00 & $1.6388+0.0049$ char $^{*}-0.0001 \operatorname{char}^{2 *}$ & 0.95 \\
\hline$\theta_{\mathrm{S}}$ & 0.5709 & 0.00 & 0.5395 & 0.00 \\
\hline$\theta_{\mathrm{r}}$ & 0.1937 & 0.00 & 0.2457 & 0.00 \\
\hline MAC & 0.2006 & 0.00 & 0.1266 & 0.00 \\
\hline RAW & $0.1290+0.0013$ char $^{*}$ & 0.21 & 0.1234 & 0.00 \\
\hline \multirow[t]{2}{*}{ PAW } & $0.1766+0.0015$ char** & 0.34 & 0.1672 & 0.00 \\
\hline & \multicolumn{4}{|c|}{ S3 } \\
\hline $\mathrm{BD}$ & 1.5651 & 0.00 & 1.6409 & 0.00 \\
\hline$\theta_{\mathrm{S}}$ & $0.5675+0.0027$ char $^{* * *}$ & 0.99 & 0.5897 & 0.00 \\
\hline$\theta_{\mathrm{r}}$ & 0.1785 & 0.00 & 0.2046 & 0.00 \\
\hline MAC & $0.2118+0.0019$ char $^{* *}$ & 0.76 & $0.1919+0.0053$ char ${ }^{*}-0.0002$ char $^{2 * *}$ & 0.91 \\
\hline RAW & $0.1349+0.0013$ char $^{* * *}$ & 0.89 & 0.1290 & 0.00 \\
\hline PAW & $0.1772+0.0013$ char $^{* *}$ & 0.91 & 0.1698 & 0.00 \\
\hline
\end{tabular}

Rate of biochar $\left(0,8,16\right.$ and $\left.32 \mathrm{Mg} \mathrm{ha}^{-1}\right)$. Soil bulk density $\left(\mathrm{BD}, \mathrm{g} \mathrm{cm}^{-3}\right)$, saturated soil moisture $\left(\theta_{\mathrm{s}}\right)$, residual soil moisture $\left(\theta_{\mathrm{r}}\right)$, macro porosity (MAC: $\left.\hat{\theta}_{0}-\hat{\theta}_{6}\right)$, rice-available water (RAW: $\left.\hat{\theta}_{6}-\hat{\theta}_{100}\right)$ and plant-available water (PAW: $\left.\hat{\theta}_{6}-\hat{\theta}_{1500}\right) .\left(\hat{\theta}_{k}\right)$ corresponds to the soil moisture content $\left(\mathrm{cm}^{3} \mathrm{~cm}^{-3}\right)$ at a matric potential $k$, estimated via nonlinear modelling of soil water retention curves (Fig. 4). Nominal significance level of $t$ tests for the biochar effect: ${ }^{* * *} p \leq 0.01,{ }^{* *} p \leq 0.05,{ }^{*} p \leq 0.10 ; R^{2}$ : the squared Pearson correlation coefficient between measured and estimated means $(n=4)$.

wood biochar (particle sized $<5000 \mu \mathrm{m}$ ) that lead to a $35 \%$ increase in PAW in a loamy sand soil. According to the van Genuchten model described by Ibrahim et al. (2013), there was an $8 \%$ increase in PAW with application of $1.5 \% \mathrm{w} / \mathrm{w}$ very fine particle sized biochar $(44-149 \mu \mathrm{m})$ in a sandy loam soil. Additionally, the SWRCs that they modelled indicate a greater impact on soil WRC at low matric potentials. However, application of fine particle size material under field conditions is difficult since it is easily moved by wind. Combination of biochar with liquid or solid fertilisers could be an option to avoid such kind of losses and capture the potential positive effect of biochar on soil WRC. Liu et al. (2012), for example, observed that application of $20 \mathrm{Mg} \mathrm{ha}^{-1}$ of biochar with $50 \mathrm{Mg} \mathrm{ha}^{-1}$ of organic compost has a more prominent positive effect on water availability than application of pure compost.

The biochar we applied in the field trial is a by-product of slow pyrolysis (under $\sim 450^{\circ} \mathrm{C}$ ) of eucalyptus wood, which resulted in a material with an intrinsic porosity $\leq 10 \mu \mathrm{m}$ (Fig. 2) and a relatively much lower SSA $\left(3.2 \mathrm{~m}^{2} \mathrm{~g}^{-1}\right)$ if 
Table 3. Response surfaces representing the effect of biochar (char) and N-fertilisation $(\mathrm{N})$ rates on total shoot dry matter (TDM, $\mathrm{Mg}^{-1}$ ), grain yield (GY, $\left.\mathrm{Mg} \mathrm{ha}^{-1}\right)$, harvest index (HI) and yield components of aerobic rice at 2 (S2) and 3 (S3) years after application in a sandy Dystric Plinthosol.

\begin{tabular}{lll}
\hline Variable & Fitted model & $R^{2}$ \\
\hline \multicolumn{1}{c}{$\mathrm{S} 2$} & \\
\hline TDM & 2.10 & 0.00 \\
GY & 1.15 & 0.00 \\
HI & $0.51+0.00172 \mathrm{~N}^{* *}-0.00003 \mathrm{~N}^{2 * * *}$ & 0.53 \\
PAN & $109+0.9824 \mathrm{~N}^{* * *}-0.0095 \mathrm{~N}^{2 * *}$ & 0.27 \\
GP & $91-1.62735 \mathrm{char}^{* *}+0.04248 \mathrm{char}^{2 *}$ & 0.18 \\
GFI & $0.81-0.0049 \mathrm{char}^{* *}-0.00066 \mathrm{~N}^{* * *}+0.00014 \mathrm{char}^{2 * * *}$ & 0.50 \\
GW & $25.56-0.03206 \mathrm{~N}^{* * *}$ & 0.32 \\
\hline & \multicolumn{1}{c}{$\mathrm{S} 3$} & 0.62 \\
\hline TDM & $2.22+0.0432 \mathrm{~N}^{* * *}-0.00044 \mathrm{~N}^{2 * * *}$ & 0.20 \\
GY & $0.49+0.002156 \mathrm{~N}^{*}$ & 0.00 \\
HI & 0.18 & 0.56 \\
PAN & $146+0.8117 \mathrm{~N}^{* *}-0.01292 \mathrm{~N}^{2 * * *}$ & 0.00 \\
GP & 132 & 0.32 \\
GFI & $0.47+0.00155 \mathrm{~N}^{* * *}$ & 0.19 \\
GW & $24.99-0.00961 \mathrm{~N}^{*}$ & \\
\hline
\end{tabular}

Rates of biochar $\left(0,8,16,32 \mathrm{Mg} \mathrm{ha}^{-1}\right)$ and $\mathrm{N}$-fertilisation $\left(0,30,60,90 \mathrm{~kg} \mathrm{ha}^{-1}\right)$. PAN: number of panicles $\mathrm{m}^{-2}$; GP: number of grains panicle ${ }^{-1}$; GFI: grain filling index; GW: 1000 -grain weight $(\mathrm{g})$. Nominal significance level of $t$ tests for the effects of biochar and $\mathrm{N}:{ }^{* * *} p \leq 0.01,{ }^{* *} p \leq 0.05$,

* $p \leq 0.10 ; R^{2}$ : the Pearson correlation coefficient between observed and estimated means $(n=16)$.

compared to a wood biochar produced under greater temperature of pyrolysis, such as the one tested by Dempster et al. (2012). They observed an astonishing increment in volumetric soil moisture content at very low matric potentials of -100 and $-1500 \mathrm{kPa}$ by 71 and $127 \%$, respectively; with application of $1.8 \% \mathrm{w} / \mathrm{w}$ biochar (SSA $273 \mathrm{~m}^{2} \mathrm{~g}^{-1}$ ) artificially packed with a sandy soil. Logically, a higher SSA biochar has more and finer pores and therefore a greater effect on soil WRC, as demonstrated by Lei and Zhang (2013). They observed a tremendous increase in soil water content between -33 and $-1500 \mathrm{kPa}$ in a sandy loam soil treated with $5 \%$ w/w woodchip biochar pyrolysed at 300,500 and $700{ }^{\circ} \mathrm{C}$ (SSA 24, 67 and $124 \mathrm{~m}^{2} \mathrm{~g}^{-1}$ ) of 39,51 and $55 \%$, respectively. We found a rise of 6,13 and $26 \%$ in PAW, accompanied by a 4,8 and $16 \%$ increase in $\theta_{\mathrm{s}}$ with $0.4,0.7$, and $1.5 \% \mathrm{w} / \mathrm{w}$ biochar, respectively (Table 2 ). Relatively, the increase in $\theta_{\mathrm{s}}$ is much higher than the $0.2 \%$ increase with $1 \% \mathrm{w} / \mathrm{w}$ biochar observed by Abel et al. (2013). The rise in PAW that we found, though, is lower than the $28 \%$ rise observed by Abel et al. (2013), and higher than the $6 \%$ rise found by Ibrahim et al. (2013) with $1 \%$ w/w biochar. Apart from differences in time after application and conditions of experimental setup, the SSA of the biochar used is probably the main cause for these discrepancies. However, neither Abel et al. (2013) nor Ibrahim et al. (2013) determined the SSA of the biochar they used. High-resolution images indicate that there are differences in the pore structure of the beech wood biochar used by Abel et al. (2013) and the one used in our study (Fig. 2). The SSA of the biochar we used is similar to the birch wood biochar (particle sized $<10000 \mu \mathrm{m}$ ) used by Karhu et al. (2011) but lower than the SSA of the eucalyptus biochar produced at $450^{\circ} \mathrm{C}$ (milled to powder) described by Borneman et al. (2007). Karhu et al. (2011) observed an effect in gravimetric soil moisture at $0 \mathrm{kPa}$ relatively higher than the effect we observed on volumetric soil moisture at $0 \mathrm{kPa}\left(\theta_{\mathrm{s}}\right)$ with application of $0.3 \% \mathrm{w} / \mathrm{w}$ biochar.

Beyond the influence that both SSA and particle size of biochar have per se on the soil WRC of a sandy soil, we must also consider the application rate. The maximum rate applied in our study was of $1.5 \% \mathrm{w} / \mathrm{w}$, which is half of the minimum rate $(3 \% \mathrm{w} / \mathrm{w})$ used in other studies that have shown great impact of biochar on soil WRC of sandy soils under artificially controlled conditions (Pereira et al., 2012; Basso et al., 2013). For instance, Basso et al. (2013) found a spectacular increase in available water content between -10 and $-1500 \mathrm{kPa}$ of 44 and $38 \%$ with application of 3 and $6 \% \mathrm{w} / \mathrm{w}$ fast pyrolysis red oak biochar, respectively. The feasibility of application of such high rates in agricultural fields should be assessed regionally. The highest rate applied in our study is already pushing the limits for practical applications. For example, according to Filiberto and Gaunt (2013), assuming yield increase and fertiliser savings, the costs for application of $25 \mathrm{Mg} \mathrm{ha}^{-1}$ biochar rate in agricultural fields may not be economically feasible. Besides the differences in the rate of 
a)

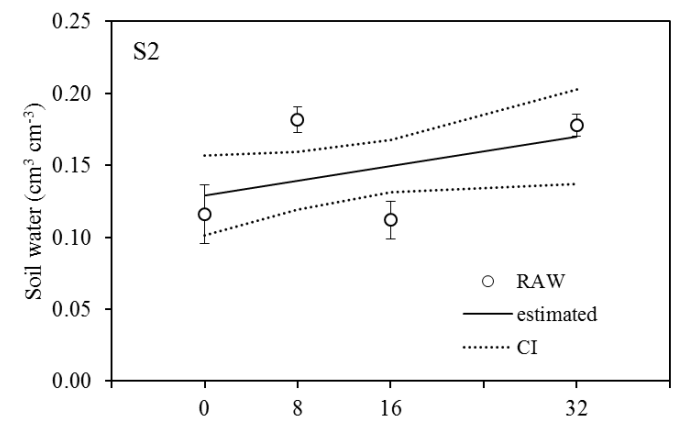

c)

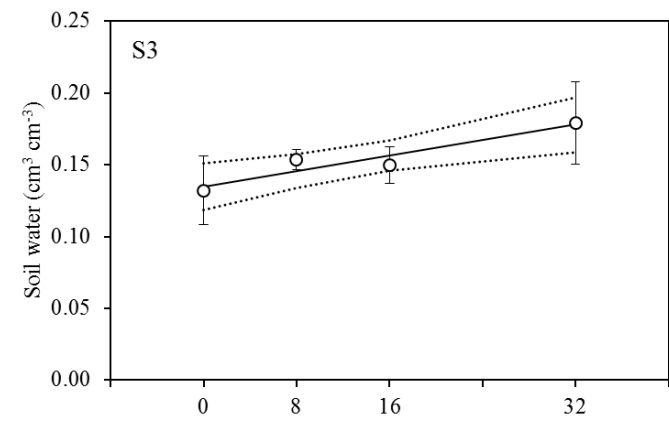

b)

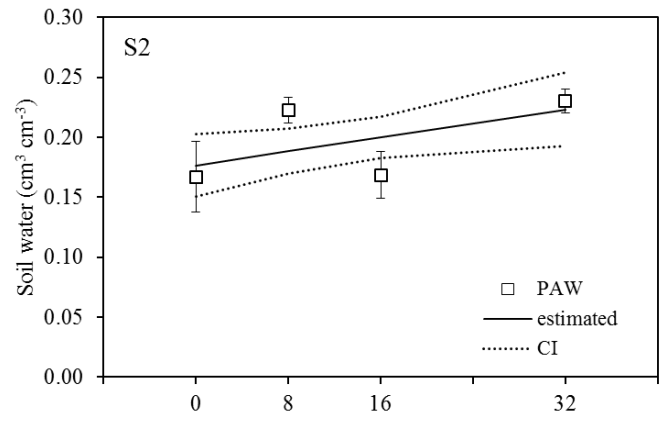

d)

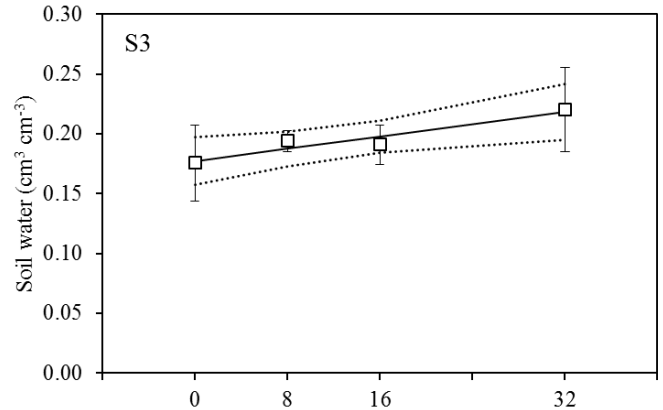

Rate of biochar $\left(\mathrm{Mg} \mathrm{ha}^{-1}\right)$

Figure 5. Rice-available water $\left(\bigcirc \mathrm{RAW}: \hat{\theta}_{6}-\hat{\theta}_{100}\right)$ and plant-available water $\left(\square \mathrm{PAW}: \hat{\theta}_{6}-\hat{\theta}_{1500}\right)$ in the upper 5-10 $\mathrm{cm}$ layer of a sandy Dystric Plinthosol at 2 (S2 - a, b) and $3(\mathrm{~S} 3-\mathbf{c}, \mathbf{d})$ years after application of biochar rate $\left(0,8,16\right.$ and $\left.32 \mathrm{Mg} \mathrm{ha}^{-1}\right)$. Symbols represent means and error bars represent standard deviation $(n=4)$. Solid lines represent estimated responses to biochar rate with respective $95 \%$ confidence intervals (CI, dotted lines). Parameter estimates of fitted linear models are presented in Table 2.

biochar used, studies are frequently conducted under artificially controlled conditions and do not evaluate the effect on plant biomass. One of the exceptions is Asai et al. (2009), who tested the effect of a wood residue biochar on saturated hydraulic conductivity accompanied by measurements on rice yield. They found an increase in saturated hydraulic conductivity with application of $16 \mathrm{Mg} \mathrm{ha}^{-1}$ biochar in the 0-5 cm surface of a silt loam soil, but no effect on rice yield.

According to a meta-analysis done by Jeffery et al. (2011) biochar application generally leads to a $10 \%$ increase in crop yields, although causes are poorly quantified and effects differ between crops. Likewise, Liu et al. (2013) found via a meta-analysis an average increase in crop productivity of $11 \%$ with biochar amendment, with greater crop responses in pot than in field experiments. We observed no response of rice GY to biochar application rate during both seasons under assessment (Table 3). Yet, in S2, GFI and GP, which are yield components strongly sensitive to water stress (Fageria, 2001), increased with biochar rate higher than $16 \mathrm{Mg}$ $\mathrm{ha}^{-1}$. In rain-fed systems soil matric potential can drop below $-100 \mathrm{kPa}$ any time during the growing season. The associated water stress leads to a reduction in overall water use efficiency by rice (Wopereis et al., 1996). Therefore, we defined rice stress free available water content as the soil moisture content between -6 and $-100 \mathrm{kPa}$ (RAW). We observed an increase of $32 \%$ in RAW with the addition of $32 \mathrm{Mg} \mathrm{ha}^{-1}$, which is equivalent to 17 to $18 \mathrm{~mm}$ in the upper $5-10 \mathrm{~cm}$ layer of the sandy loam soil. This additional amount of water would be sufficient to satisfy the crop demand for approximately 4 additional days without rainfall, considering that the evapotranspiration rate in an uncovered soil is ca. $5 \pm 0.5 \mathrm{~mm} \mathrm{day}^{-1}$ during the critical stage of rice production under aerobic conditions (around 45 to $75 \mathrm{DAE}$ ) in the Brazilian savannah (Stone and Moreira, 2005). During the critical period for rice production in seasons under assessment in this study, in January/February 2011 (S2) and January/February 2012 (S3), the amount of rainfall was high $(\sim 650 \mathrm{~mm})$ and twice the amount during the critical period in previous seasons, in February/March 2009 and January/February 2010 (Fig. 1). If there is a positive effect of biochar on RAW of the sandy loam soil, then the effect on rice GY would be a consequence of lower precipitation rate, such as in the first seasons of the trial reported by Petter et al. (2012). Throughout the latest 35 years (from 1979 to 
2013) average precipitation rate during the months of January and February in the municipality where the field trial is located was $507 \mathrm{~mm}$ and the frequency of an amount of rainfall lower than $650 \mathrm{~mm}$ was $74 \%$ (Agritempo, 2014). In other words, in this region of Brazil's tropical savannah, rainfall during the critical period for rice production is frequently lower than $650 \mathrm{~mm}$. This means that application of biochar could be sound agronomic practice that could reduce water stress and improve yield stability. If the application of biochar can optimise water use, then increased rice productivity seems a conceivable result, especially for farmers relying on scarce resources in tropical and subtropical regions (Nabahungu and Visser, 2013; Masood et al., 2014). Furthermore, salinisation is a worrying subject in rice production areas in arid regions of the world (Ahmad et al., 2013; Ghafoor et al., 2012) and an increase in soil moisture with wood biochar application can potentially help to reduce this problem.

Finally, we have demonstrated that NLM can be used as an innovative analytical tool to model SWRC and compare the shape parameters $\alpha$ and $n$ via formal tests. By using a NLM model, we were able to account for the random effect of latent variables related to measurements taken in the same sample unit within a specific location (plot), leading to a reduction in the uncertainty of estimation of the SWRCs (Fig. 3). By using the SAS program, results of model fitting were generated by year and soil layer in one run, facilitating the management of the large data set.

\section{Conclusions}

We found a consistent increase in plant-available water and rice-available water in the upper soil layer of around 0.8 and $1 \%$ for each $\mathrm{Mg} \mathrm{ha}^{-1}$ biochar amendment, respectively, 2 and 3 years after its application. The impact on water retention capacity of the sandy loam soil is mostly related to an effect in overall porosity of the soil matrix and did not result in increased rice yield, most likely because, in both seasons under study, rainfall during the critical period for rice production exceeded $650 \mathrm{~mm}$. The use of biochar as a soil amendment could be a worthwhile strategy to improve yield stability in water-limited seasons. These findings call for longer term field trials with feasible amounts of biochar application, which are usually lower than those applied in artificially controlled studies. In addition, detailed analyses of all biochar properties should become a standard procedure in order to better target its use as a soil amendment - different sources and methods of creating biochar can lead to very different char properties. Important properties to be reported are specific surface area and particle size. Expression of the rate of biochar on a dry mass basis can also facilitate comparison of findings. In addition to our main findings, we also demonstrated the utility and adequacy of nonlinear mixed modelling to make statistical inferences on SWRCs by accounting for spatial variability and expected dependencies arising from measurements taken in the same sample unit within a specific plot in the field trial.

Acknowledgements. This study was funded by the Brazilian Agricultural Research Corporation (EMBRAPA, project no. 03.10.01.009). We thank Embrapa Rice and Beans' staff for the support provided during data collection and analysis and José A. A. Moreira, João Carlos Medeiros and Willem Hoogmoed for enlightening discussions about SWRCs. We also acknowledge CNPq for providing PQ Fellowship and the Institutes of Physics (LABMIC) and Chemistry at the Federal University of Goiás (UFG) where SEM images and BET analysis, respectively, of biochar were made. We are grateful to the farmers Carlos A. Petter and Marino Petter for their support for the establishment of the field trial on their farm (Estrela do Sul). We also thank the State University of Mato Grosso (Unemat, Campus Nova Xavantina) for providing facilities, and Diogo Machado, Laissa Gonçalves, Leidimar de Morais and Fabrício Andrade who were involved in the maintenance of the field trial.

Edited by: A. Cerdà

\section{References}

Abel, S., Peters, A., Trinks, S., Schonsky, H., Facklam, M., and Wessolek, G.: Impact of biochar and hydrochar addition on water retention and water repellency of sandy soil, Geoderma, 202203, 183-191, 2013.

ABRAF, Brazilian Association of Forest Plantation Producers: Statistical yearbook 2011, base year 2010, Brasília, 130 pp., 2011.

Agritempo: The Brazilian System for Meteorological Monitoring, Embrapa Informática Agropecuária, available at: http://www. agritempo.gov.br/index.php, 2014.

Ahmad, S., Ghafoor, A., Akhtar, M. E., and Khan, M. Z.: Ionic displacement and reclamation of saline-sodic soils using chemical amendments and crop rotation, Land Degrad. Develop., 24, 170178, doi:10.1002/ldr.1117, 2013.

Araújo, A. S. F. de, Eisenhauer, N., Nunes, L. A. P. L., Leite, L. F. C., and Cesarz, S.: Soil surface-active fauna in degraded and restored lands of Northeast Brazil, Land Degrad. Develop., doi:10.1002/ldr.2247, 2013.

Asai, H., Samson, B. K., Stephan, H. M., Songyikhangsuthor, K., Homma, K., Kiyono, Y., Inoue, Y., Shiraiwa, T., and Horie, T.: Biochar amendment techniques for upland rice production in Northern Laos 1 . Soil physical properties, leaf SPAD and grain yield, Field Crop Res., 111, 8-84, 2009.

Assad, E. and Pinto, H. S.: Global Warming and the Future Scenarios Brazilian Agriculture, Unicamp/Embrapa, available in Portuguese at: http://www.agritempo.gov.br/climaeagricultura/ -download.html, 84 pp., 2008.

Basso, A. S., Miguez, F. E., Laird, D. A., Horton, R., and Westgate, M.: Assessing potential of biochar for increasing water-holding capacity of sandy soils, Glob. Change Biol. Bioenerg., 5, 132143, 2013.

Bornemann, L. C., Kookana, R. S., and Welp, G.: Differential sorption behaviour of aromatic hydrocarbons on charcoals prepared 
at different temperatures from grass and wood, Chemosphere, 67 , 1033-1042, 2007.

Brunauer, S., Emmet, P. H., and Teller, E.: Adsorption of gases in multimolecular layers, The Bureau of Chemistry and Soils and George Washington University, 60, 309-319, 1938.

Dempster, D. N., Jones, D. L., and Murphy, D. V.: Clay and biochar amendments decreased inorganic bout not dissolved organic nitrogen leaching in soil, Soil Res., 50, 216-221, 2012.

Dourado-Neto, D., Nielsen, D. R., Hopmans, J. W., Reichardt K., and Bacchi, O. O. S.: Software to model soil water retention curves (SWRC, version 2.00), Sci. Agric., 57, 191-192, 2000.

EMBRAPA, Brazilian Agricultural Research Corporation: Manual de métodos de análise de solo, Embrapa Solos, Documentos 1, 212 pp., 1997.

EMBRAPA, Brazilian Agricultural Research Corporation: Informações técnicas sobre o arroz de terras altas, Estados de Mato Grosso e Rondônia, safra 2007/2008, Embrapa Arroz e Feijão, Documentos 212, 84 pp., 2007.

Fageria, N. K.: Nutrient management for improving upland rice productivity and sustainability, Commun. Soil Sci. Plan., 32, 2603 $2629,2001$.

Fernández, C., Vega, J. A., Jiménez, E., Vieira, D. C. S., Merino, A., Ferreiro, A., and Fonturbel, T.: Seeding and mulching + seeding effects on post-fire runoff, soil erosion and species diversity in Galicia (NW Spain), Land Degrad. Develop., 23, 150-156, doi:10.1002/ldr.1064, 2012.

Fialho, R. C. and Zinn, Y. L.: Changes in soil organic carbon under eucalyptus plantations in Brazil: a comparative analysis, Land Degrad. Develop., doi:10.1002/ldr.2158, 2012

Filiberto, D. M. and Gaunt, J. L. Practicality of biochar additions to enhance soil and crop productivity, Agriculture, 3, 715-725, 2013.

Freitas Jr., E. and Silva, E. M.: The use of the centrifuge for determining the soil moisture characteristic curve in one step, Pesqui. Agropecu. Bras., 19, 1423-1428, 1984.

Ghafoor, A., Murtaza, G., Rehman, M. Z., Saifullah, and Sabir, M.: Reclamation and salt leaching efficiency for tile drained saline-sodic soil using marginal quality water for irrigating rice and wheat crops, Land Degrad. Develop., 23, 1-9, doi:10.1002/ldr.1033, 2012.

Glaser, B., Haumaier, L., Guggenberger, G., and Zech, W.: The 'Terra Preta' phenomenon: a model for sustainable agriculture in the humid tropics, Naturwissenschaften, 88, 37-41, 2001.

Glaser, B., Lehmann, J., and Zech, W.: Ameliorating physical and chemical properties of highly weathered soils in the tropics with charcoal - a review, Biol. Fert. Soils, 35, 219-230, 2002.

IBGE, The Brazilian Institute of Geography and Statistics: Systematic Survey of Agricultural Production, available at: http: //www.ibge.gov.br/ (last access: 15 July 2013), 2012.

Ibrahim, H. M., Al-Wabel, M. I., Usman, A. R. A., and Al-Omran, A.: Effect of Conocarpus biochar application on the hydraulic properties of a sandy loam soil. Soil Sci., 178, 165-173, 2013.

Jeffery, S., Verheijen, F. G. A., Van Der Velde, M., and Bastos, A. C.: A quantitative review of the effects of biochar application to soils on crop productivity using meta-analysis, Agr. Ecosyst. Environ., 144, 175-187, 2011.

Karhu, K., Mattila, T., Bergström, I., and Regina, K.: Biochar addition to agricultural soil increased $\mathrm{CH}_{4}$ uptake and water holding capacity - results from short-term pilot field study, Agr. Ecosyst. Environ., 140, 309-313, 2011.

Kookana, R. S., Sarmah, A. K., Van Zwieten, L., Krull, E., and Singh, B.: Biochar application to soil: agronomic and environmental benefits and unintended consequences, Adv. Agron., 112, 103-143, 2011.

Lee, J.-W., Park, C.-M., and Rhee, H.: Revegetation of decomposed granite roadcuts in Korea: developing digger, evaluating cost effectiveness, and determining dimensions of drilling holes, revegetation species, and mulching treatment, Land Degrad. Develop., 24, 591-604, doi:10.1002/ldr.2248, 2013.

Lei, O. and Zhang, R.: Effects of biochars derived from different feedstocks and pyrolysis temperatures on soil physical and hydraulic properties, J. Soils Sediments, 13, 1561-1572, 2013.

Liu, J., Schulz, H., Brandl, S., Miehtke, H., Huwe, B., and Glaser, B.: Short-term effect of biochar and compost on soil fertility and water status of a Dystric Cambisol in NE Germany under field conditions, J. Plant Nutr. Soil Sci., 175, 698-707, 2012.

Liu, X., Zhang, A., Ji, C., Joseph, S., Bian, R., Li, L., Pan, G., and Paz-Ferreiro, J.: Biochar's effect on crop productivity and the dependence on experimental conditions - a meta-analysis of literature data, Plant Soil, 373, 583-594, 2013.

MacCullagh, P. and Nelder, J. A.: Chapter 3: models for continuous data with constant variance, in: Generalized Linear Models, edited by: McCullagh, P. and Nelder, J. A., Chapman and Hall, New York, 35-71, 1983.

Masood, A. I., Bastiaans, L., van Oort, P., Ahmad, R., Ashraf, M. Y., and Meinke, H.: Nitrogen and crop performance of rice under aerobic conditions in a semiarid subtropical environment, Agron. J., 106, 199-211, doi:10.2134/agronj2013.0262, 2014.

Mcdonagh, J., Lu, Y., and Semalulu, O.: Adoption and adaptation of improved soil management practices in the Eastern Ugandan hills, Land Degrad. Develop., 25, 58-70, doi:10.1002/ldr.1143, 2014.

Mualem, Y.: A new model for predicting the hydraulic conductivity of unsaturated porous media, Water Resour. Res., 12, 513-522, 1976.

Nabahungu, N. L. and Visser, S. M.: Farmers' knowledge and perception of agricultural wetland management in Rwanda, Land Degrad. Develop., 24, 363-374, doi:10.1002/ldr.1133, 2013.

Omuto, T. C., Minasny, B., McBratney, A. B., and Biamah, E. K.: Nonlinear mixed effect modelling for improved estimation of water retention and infiltration parameters, J. Hydrol., 330, 748758, 2006.

Peel, M. C., Finlayson, B. L., and McMahon, T. A.: Updated world map of the Köppen-Geiger climate classification, Hydrol. Earth Syst. Sci., 11, 1633-1644, doi:10.5194/hess-11-16332007, 2007.

Pereira, R. G., Heinemann, A. B., Madari, B. E., Carvalho, M. T. M., Kliemann, H. J., and dos Santos, A. P.: Transpiration response of upland rice to water deficit changed by different levels of eucalyptus biochar, Pesqui. Agropecu. Bras., 47, 716-721, 2012.

Petter, F. A., Madari, B. E., Silva, M. A. S., Carneiro, M. A. C., Carvalho, M. T. M., Marimon Jr., B. H., and Pacheco, L. P.: Soil fertility and upland rice yield after biochar application in the Cerrado, Pesquisa Agropecuária Brasileira, 47, 699-706, 2012.

Prats, S. A., Malvar, M. C., Vieira, D. C. S., MacDonald, L., and Keizer, J. J.: Effectiveness of hydromulching to reduce runoff and 
erosion in a recently burnt pine plantation in Central Portugal, Land Degrad. Develop., doi:10.1002/ldr.2236, 2013.

SAS Institute Inc.: 2008. SAS Version $9.2^{\circledR}$ 2002-2008, Cary, NC, USA, 2008.

Stone, L. F. and Moreira, J. A. A.: Irrigação do arroz de terras altas em função da porcentagem de cobertura do solo pela palhada no sistema plantio direto, Embrapa Arroz e Feijão, Circular Técnica 69, 2005.
Tryon, E. H.: Effect of charcoal on certain physical, chemical and biological properties of forest soils, Ecol. Soc. Am., 18, 81-115, 1948.

Van Genuchten, M. Th.: A closed-form equation for predicting the hydraulic conductivity of unsaturated soils, Soil Sci. Soc. Am. J., 44, 892-898, 1980.

Wopereis, M. C. S., Kropff, M. J., Maligaya, A. R., and Tuong, T. P.: Drought-stress responses of two lowland rice cultivars to soil water status, Field Crop. Res., 46, 21-39, 1996. 